Original Research Paper

\title{
Different Eye Physiology of Mud Crab (Scylla Serrata) in Different Life Stage Found in Semarang Territorial Waters
}

\author{
${ }^{1}$ Aristi Dian Purnama Fitri, ${ }^{1}$ Herry Boesono, ${ }^{2}$ Agus Sabdono and ${ }^{1}$ Fahresa Nugraheni \\ ${ }^{I}$ Department of Capture Fisheries, \\ ${ }^{2}$ Department of Marine Science, \\ Faculty of Fisheries and Marine Science, Diponegoro University, Semarang, Indonesia
}

Article history

Received: 19-03-2017

Revised: 27-11-2017

Accepted: 27-01-2018

Corresponding Author: Aristi Dian Purnama Fitri Department of Capture Fisheries, Faculty of Fisheries and Marine Science, Diponegoro University, Semarang, Indonesia Email: aristidian@fisika.undip.ac.id

\begin{abstract}
Mud crabs use their eyes function to guide their movement activities i.e., to avoid predator and to support their environment orientation. In tropical environment such as Indonesia, mud crabs live in mangrove area as their habitat. To support their visual acuity, mud crabs depend on the number of con sell as photoreceptor and carapace width. The purpose of this study is to prove whether mud crab eye physiology is different between life stages (juvenile, sub-adult and adult stadia) especially in Semarang territorial water. Histology methods were used to determine the density of cone cell on three life stages. The highest number of eye cell in juvenile, sub-adult and adult are 25, 15 and 13 units, respectively and found in frontal inner side. The visual acuity in juvenile is $6.005 \times 10^{-3}$ $7.46 \times 10^{-3}$; sub-adult is $9.17 \times 10^{-3}-15.4 \times 10^{-3}$; and the adult is $16.03 \times 10^{-3}$ $19.6 \times 10^{-3}$. The results indicate that the increase of visual acuity follows the growth of carapace width in mud crabs.
\end{abstract}

Keywords: Eye Physiology, Mud Crab, Life Stage, Semarang Territorial Water

\section{Introduction}

Mud crab's (Scylla serrata) is a group of crabs live in mangrove ecosystem such as Semarang waters which becomes an abundantly fishery-catches commodity in Semarang water, North Java Sea $\left(07^{\circ} 00 \mathrm{~S} 11^{\circ} 24^{\prime} \mathrm{E}\right)$. The crabs are founding aquatic habitats ranging from estuarine to coastal, (Grubert and Phelan, 2007) and abundantly can be found in mangrove area. In Semarang, fisherman catches the crabs using collapsible trap or pots with using bait to maximize the catch and attract mud crabs to enter. Barnes and Jon (1990), As discussed by Zeil and Hemmi (2006), Crabs like most other higher crustaceans have movable eyes on stalk where in the case of state mud crab, visual field allows it to simultaneously monitor everything that happen around it. Discussed by Insausti et al. (2012), the visual field of mud crabs can detect the danger such as, predator, prey food and interaction to neighbor.

Similar with mantis shrimp, mud crabs have poor visual acuity power in seeing objects in a straight line (Barnes and Jon, 1990). Crab eye position is different with Shrimp group therefore its visual character based on their physiology is different according to previous study Zeil and Hemmi (2006) in fiddler crabs. Different life stage will influence the visual acuity in their life stages. As example, visual power in fish studied by Fitri (2005), (Ephinephelus sp) is differ according to their age while Fitri (2012) has shown that visual acuity will influence visual sighting towards an object. But in mud crabs, to our knowledge, the relation between their eye physiology to the characteristics of Visual Acuity (VA), visual axis and Maximum Sighting Distance (MSD) in the different life stages (juvenile, sub adult and adult crabs) have never been studied before. Therefore, the purpose of this study is to prove whether mud crabs eye physiologies, i.e., Visual Acuity (VA), visual axis and Maximum Sighting Distance (MSD), are different in different life stages (juvenile, sub adult and adult crabs).

\section{Materials and Methods}

The research descriptively analyzes the mud crab eyes by a dissection of 30 mud crab involving 3 life stages: Juvenile (carapace width $<7 \mathrm{~cm}$ ), sub adult (carapace width $7-11 \mathrm{~cm}$ ) and adult (carapace width $<15 \mathrm{~cm}$ ). The 
samples werecaught by local fisherman using collapsible trap $(1 \times \mathrm{w} \times \mathrm{h}: 50 \times 40 \times 25 \mathrm{~cm})$ in Tambak Lorok, Semarang waters. Five traps were set with Leiognathus fish as bait and were immersed in $3 \mathrm{~h}$. This research used fresh (alive) crabs which were caught in 2 weeks between January-February 2016. The eyes were freshly taken after the crabs were directly killed and were soaked into a fixation solvent for a maximum of 48 hours. Then the solvent was replaced by alcohol with $70 \%$ purity.

Histological analyses was used to analyze the microstructure of the cone cell eyes of mud crab by dissecting the eye and immediately soak it into fixative solvent (Ethanol 100\% $330 \mathrm{~mL}$, Formaldehyde $220 \mathrm{~mL}$, Acetate acid $115 \mathrm{~mL}$, Aquadest $335 \mathrm{~mL}$ ) before sealed for $24 \mathrm{~h}$ soaking time to keep the eye tissue perfect.This procedure was used by the group of Fitri (2005); Purbayanto et al. (2010) and another histological analyses was used by Purbayanto et al. (2010); Purbayanto (1999); Shiobara et al. (1998); Tamura (1957). The dissection of the eye was done with the assumption of both right and left eye are similar. Early research by Epifanio and Cohen (2016) shown that visual acuity of both monocular and binocular eye were similar to detect an object. Fig. 1 shows front side of mud crab. It shows both right and left eyes which are then tested by cutting them to decide visual acuity and visual axis. The front dissection of the crab eyes is illustrated at Fig. 2 respectively.

The eye dissection was done by cutting the longitudinal section into 4 parts: 2 parts in frontal side (inner frontal side, outer frontal side), 2 parts in bottom/back side (inner bottom/back side and outer bottom side). Each specimen was soaked by eosin and methionine and was observed under microscope with $400 x$ magnification to calculate the number of eye cell in $0.01 \mathrm{~mm}^{2}$ visual field. The highest number of eye cell in each dissection part was used as a based to determine the visual acuity, visual axis and maximum sighting distance.

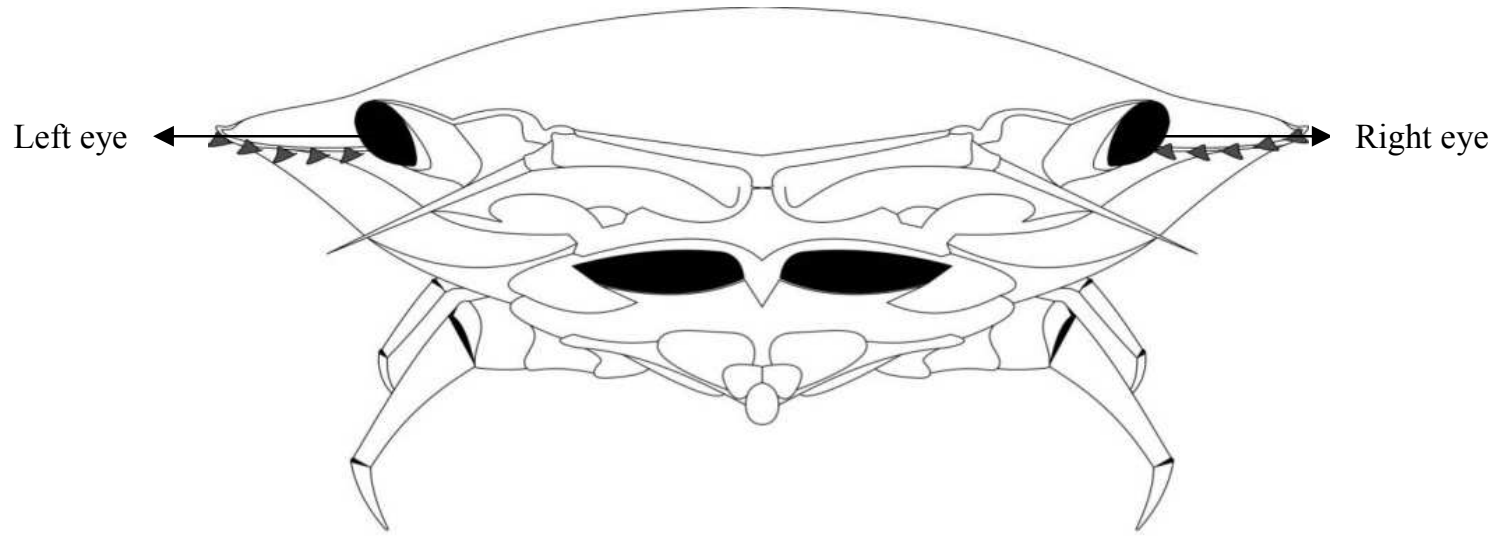

Fig. 1: Frontal side of mud crab; Sources: Original documentation
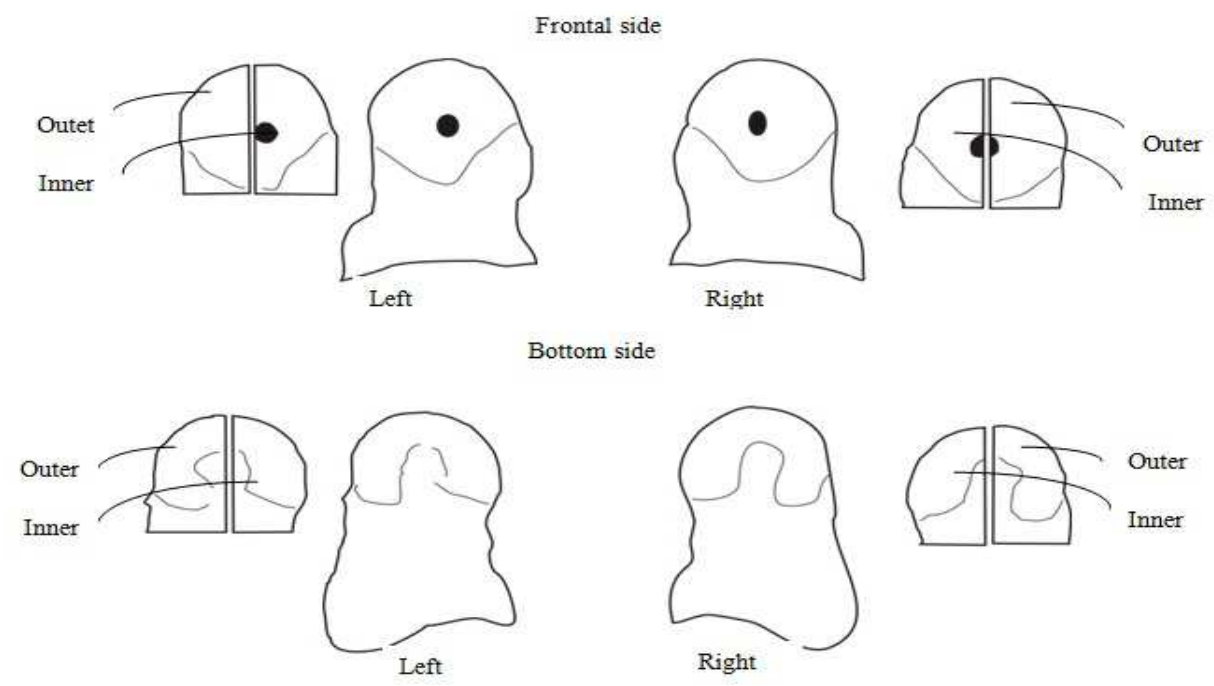

Fig. 2: Dissection of crab eye; Sources: Original documentation 
The number of cone cell and lens diameter was used to know the Minimum Separable Angle (MSA) of Visual Acuity (VA). MSA can be obtained by using the following equation (Shiobara et al., 1998; Purbayanto, 1999):

$$
\begin{gathered}
M S A \alpha_{\text {rad }}=1 / F \times[(2 \times 0.1 \times(1+0.25)) /(\sqrt{ } n)] \\
\text { Visual acuity } V A=\left(\alpha_{\text {rad }} \times 180 / \pi \times 60\right)^{-1}
\end{gathered}
$$

where, $F$ is the focus length $(F=0.25 \times 1 / 2 \mathrm{~d}), \mathrm{d}$ is the lens diameter, $n$ is the total of eye cell in $0.01 \mathrm{~mm}^{2}, \pi$ is 3.14 and, $\alpha_{\text {rad }}$ is unit of MSA.
The Maximum Sighting Distance (MSD) is determined as the maximum distance of object view depends on diameter value and MSA (Fitri, 2005):

$$
M S D=\left(d / \alpha_{r a d}\right)
$$

where, MSD is in meter $(\mathrm{m}), d$ is the diameter of lens $(\mathrm{mm})$ and $\alpha_{\text {rad }}$ is the unit of MSA

\section{Results}

Characteristics of crab eye particularly at different carapace width of photoreceptor cells at $0.01 \mathrm{~mm}^{2}$ area, magnified by 400 times $\times$ magnification in histological section, is shown in Fig. 3.
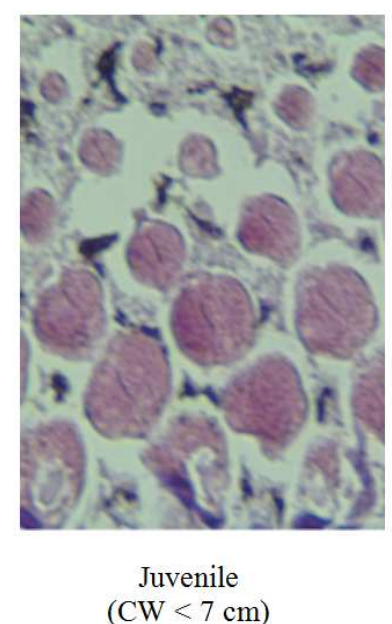

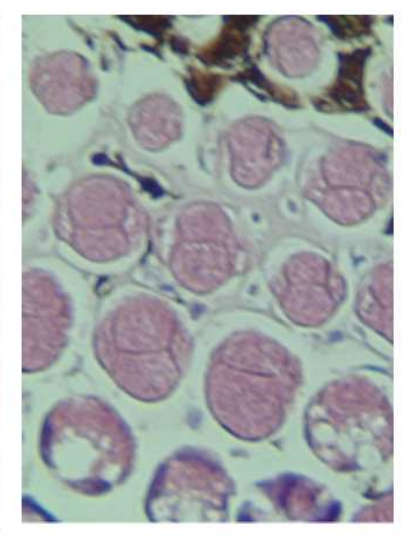

Subadult (CW 7-11 cm)

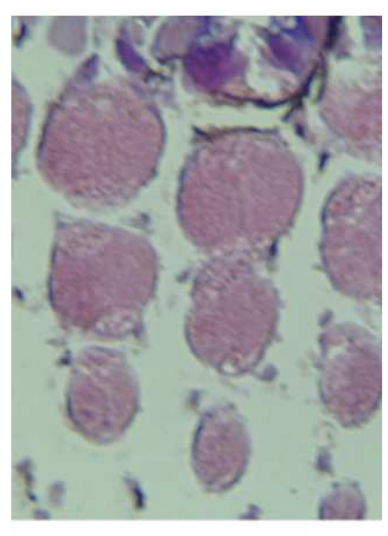

Adult
$(\mathrm{CW}>11 \mathrm{~cm})$

Fig. 3: The photomicrographs in histological section of eye crab

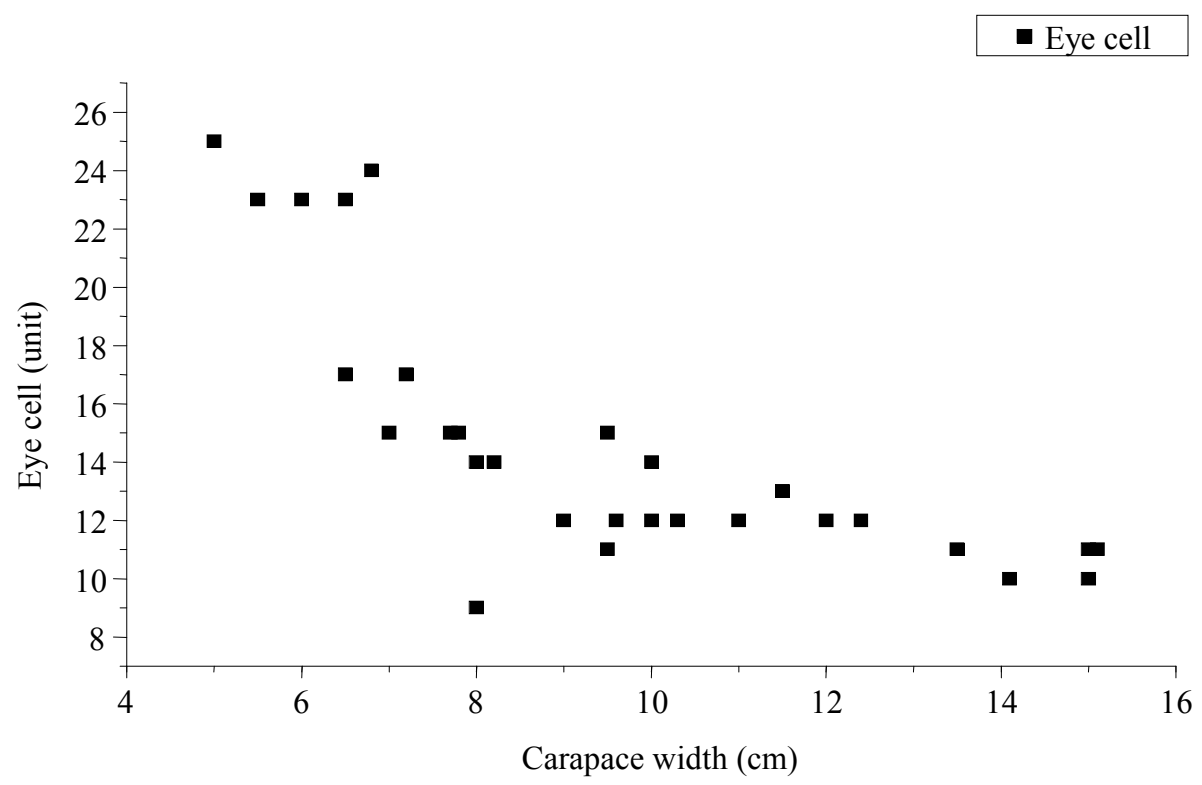

Fig. 4: The relation between carapace width and the density of eye cell 
Figure 4 shows the relation between the density of eye cell and eye diameters as the crab eye characteristics.

The eye cells density is counted by the number of cell in each life stage. Figure 4 shows the increase of life stage (measured by carapace width) is opposed the number of the cell.

Figure 5 shows the increase of life stage followed by the increase of eye diameter. It is seen that Fig. 5 diagram is reversed to Fig. 4 where the density of eye cell were decrease by the increasing of carapace width.

The determination of visual acuity crab was based on the value of the minimum separable angle (MSA), where the value of the MSA will be different due to differences in size crab carapace width. A value that indicates the width carapace, MSA and visual acuity are listed in Table 1.

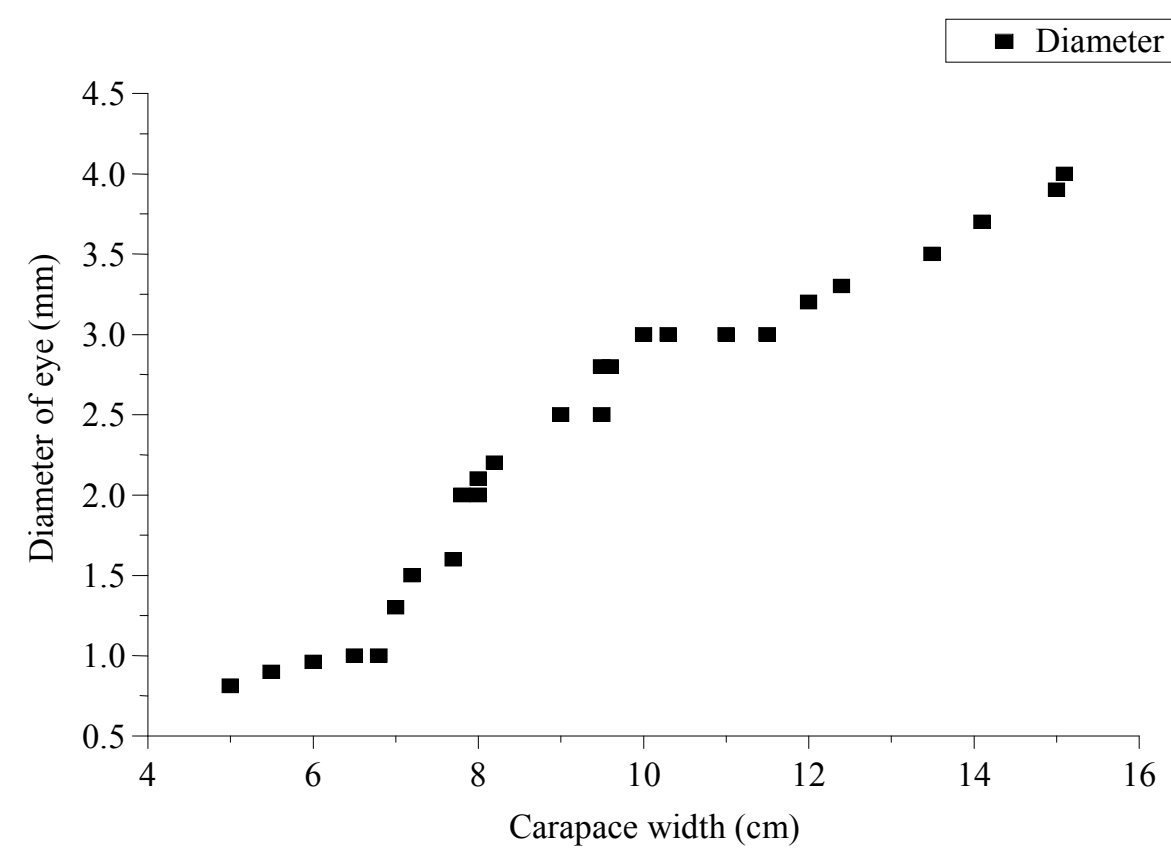

Fig. 5: The relation between carapace width and eye diameter

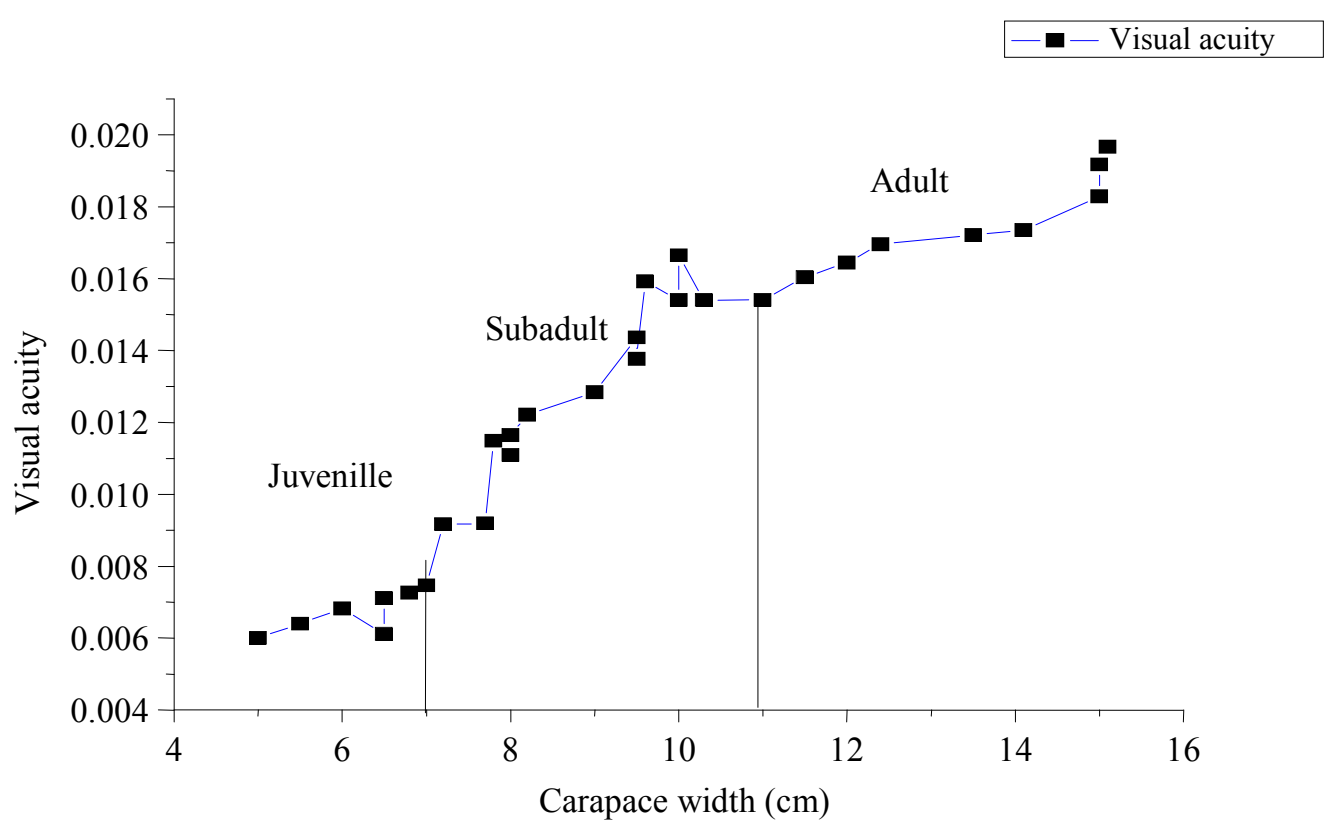

Fig. 6: The relation between carapace width and visual acuity in Scylla serrata 


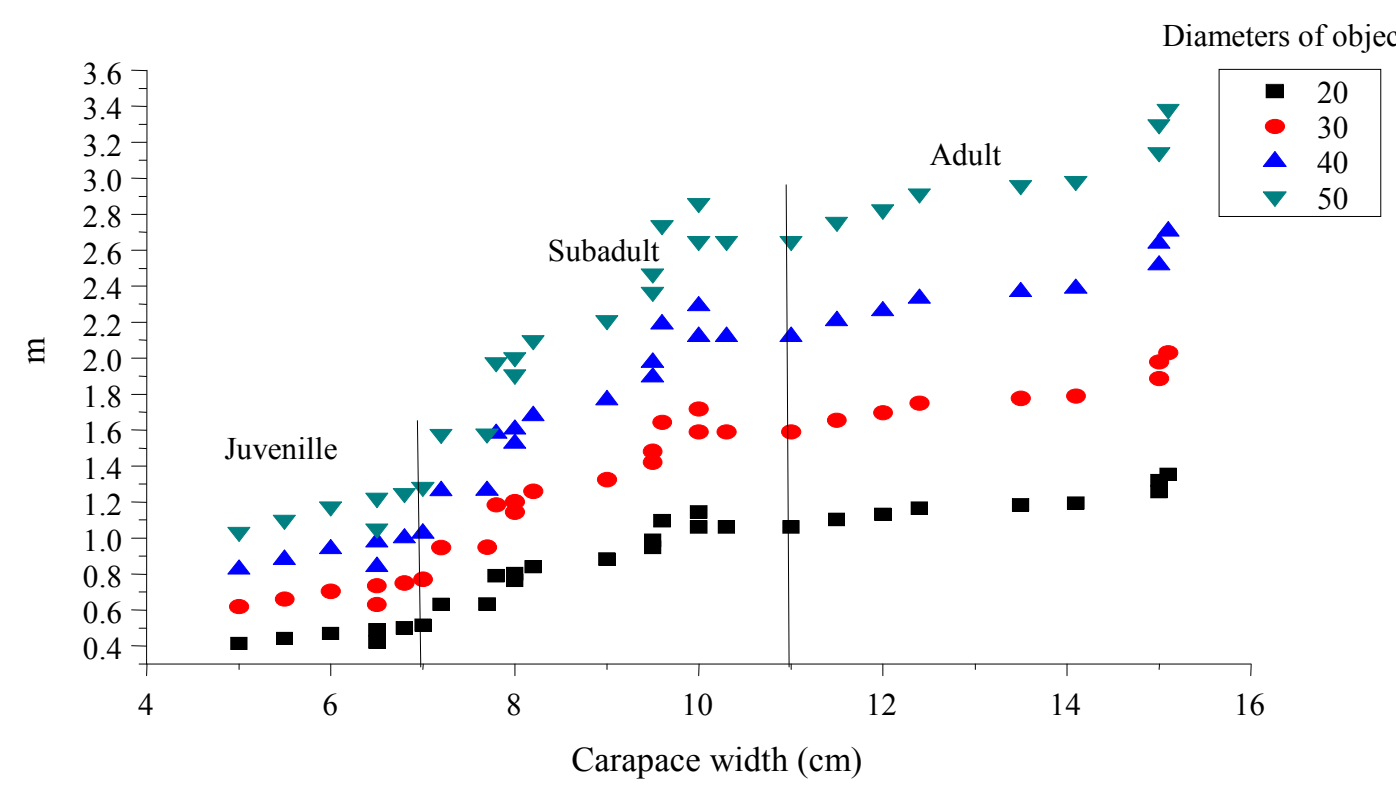

Fig. 7: The relation between Maximum Sighting Distance (MSD) towards the object

Table 1: Minimum separable angle and visual acuity

\begin{tabular}{|c|c|c|}
\hline Carapace width $(\mathrm{cm})$ & Minimum separable angle ( $\alpha \mathrm{rad})$ & Visual acuity \\
\hline \multicolumn{3}{|l|}{ Juvenile } \\
\hline 5 & 0.048414427 & 0.006005251 \\
\hline 5.5 & 0.045427977 & 0.006400038 \\
\hline 6 & 0.042588728 & 0.006826707 \\
\hline 6.5 & 0.047556005 & 0.006113650 \\
\hline 6.5 & 0.040885179 & 0.007111153 \\
\hline 6.8 & 0.040024342 & 0.007264099 \\
\hline 7 & 0.038944026 & 0.007465607 \\
\hline \multicolumn{3}{|l|}{ Sub adult } \\
\hline 7.2 & 0.031704003 & 0.009170475 \\
\hline 7.7 & 0.031642021 & 0.009188439 \\
\hline 7.8 & 0.025313617 & 0.011485549 \\
\hline 8 & 0.026202083 & 0.011096094 \\
\hline 8 & 0.024954364 & 0.011650899 \\
\hline 8.2 & 0.023820075 & 0.012205704 \\
\hline 9 & 0.022641187 & 0.012841234 \\
\hline 9.5 & 0.020250893 & 0.014356936 \\
\hline 9.5 & 0.021114240 & 0.013769891 \\
\hline 9.6 & 0.018259022 & 0.015923130 \\
\hline 10 & 0.018867656 & 0.015409481 \\
\hline 10 & 0.017468055 & 0.016644141 \\
\hline 10.3 & 0.018867656 & 0.015409481 \\
\hline 11 & 0.018867656 & 0.015409481 \\
\hline \multicolumn{3}{|l|}{ Adult } \\
\hline 11.5 & 0.018127457 & 0.016038696 \\
\hline 11.5 & 0.018127457 & 0.016038696 \\
\hline 12 & 0.017688427 & 0.016436779 \\
\hline 12.4 & 0.017152414 & 0.016950429 \\
\hline 13.5 & 0.016891392 & 0.017212364 \\
\hline 14.1 & 0.016758228 & 0.017349136 \\
\hline 15 & 0.015898832 & 0.018286927 \\
\hline 15 & 0.015158941 & 0.019179491 \\
\hline 15.1 & 0.014779968 & 0.019671273 \\
\hline
\end{tabular}




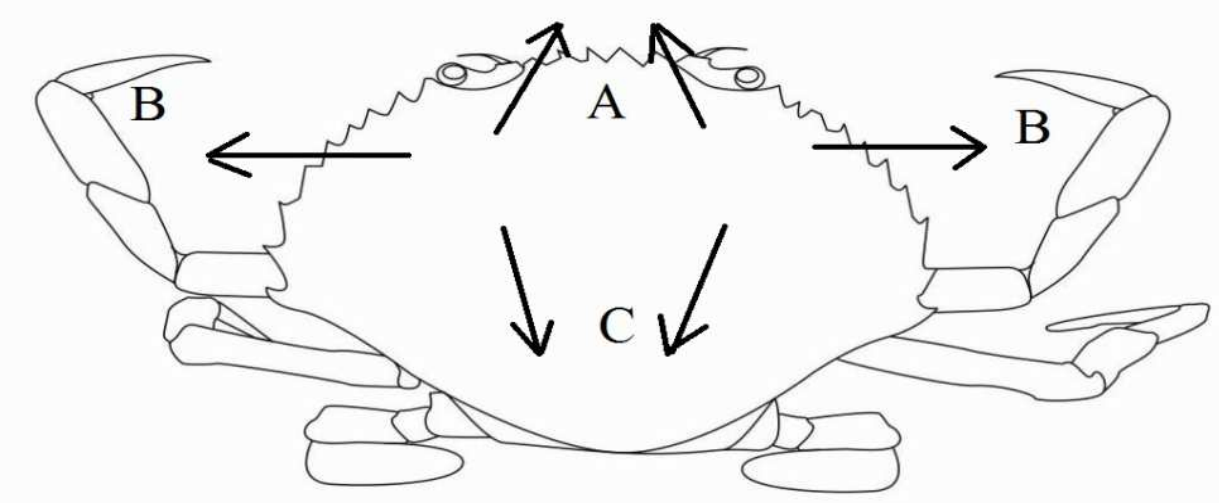

Fig. 8: Inner Frontal side (A), Outer Frontal side and Outer Back side (B), Inner Back side (C)

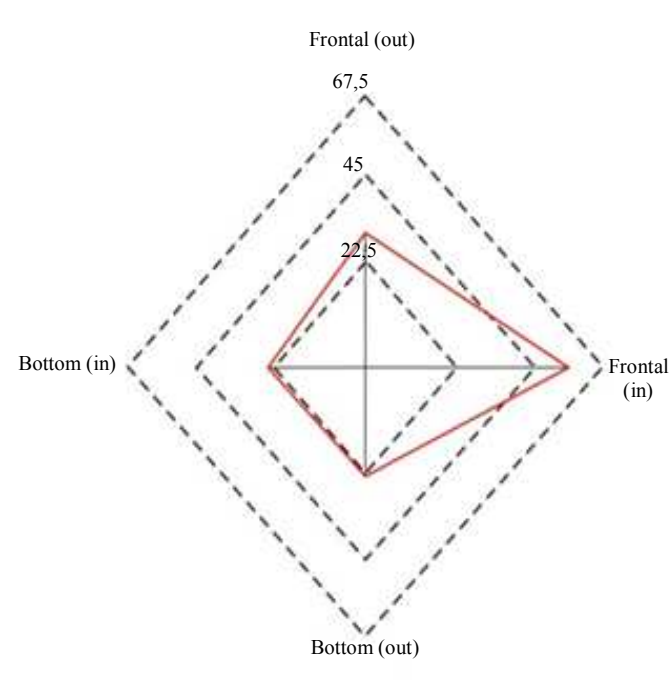

Juvenille

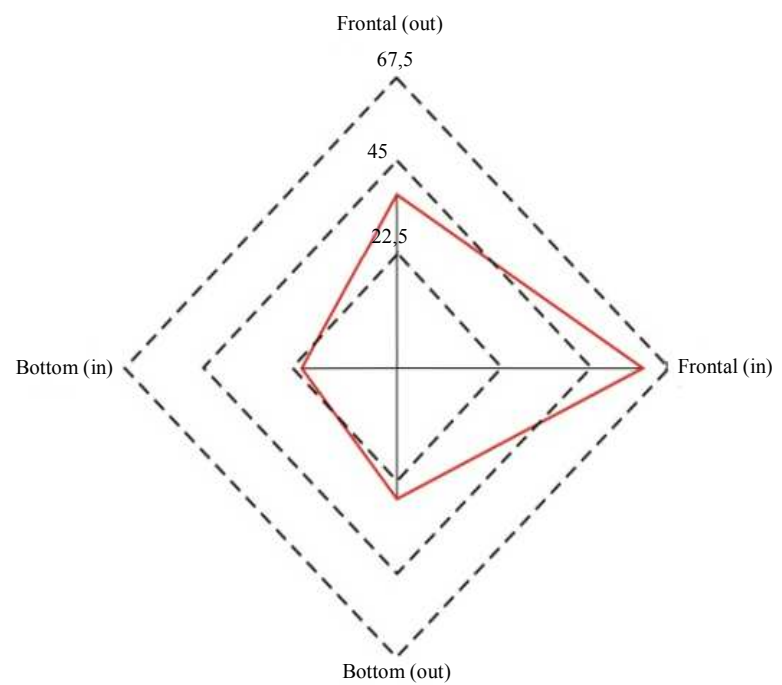

Subadult

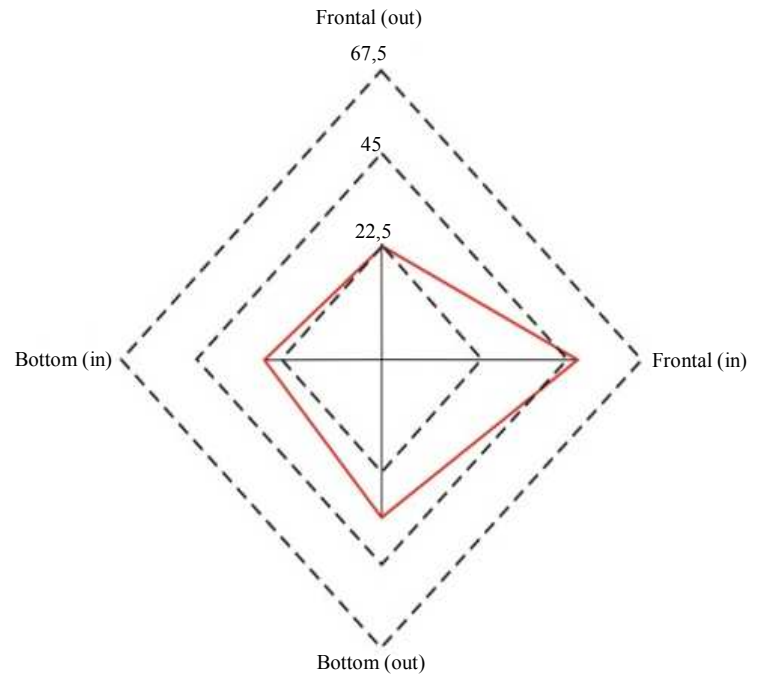

Adult

Fig. 9: The visual axis from different life stages 
The result from Table 1 shows that Minimum separable angle in the juvenile, sub adult and adult stage in the range of $0.048414427-0.038944026,0.031704003-$ 0.018867656 and $0.016038696-0.019671273$ respectively. Each MSA value was decreased with the increased of carapace width (age). Guma'a (1982) stated that the visual acuity of animal increased along with its growth by size and life stadia, this also occured for mud crab. For more detail of the visual acuity of mud crabs is shown at Fig. 6.

Figure 7 shows the relation between Maximum Sighting Distance (MSD) in different diameter of object. MSD is a calculation based on the data characteristics of the eye crab associated with the value of visual acuity associated with an object diameter objects, aims to assess the ability of crab see specific size diameter object first. The chart shows the relation maximum sighting distance in the different life stage having different capabilities in seeing object at different diameter.

\section{Visual Axis}

Visual axis regarded as the density of eye cell on each side of eyes part. Eye histology do by cutting the crab eyes in to 4 pieces, outer front, inner front, outside bottom/back side, inner bottom in each eye (right and left) show in Fig. 2. Fitri (2012), the visual axis obtained by drawing a straight line from retina which has the highest cell density.

Figure 8 depicts view direction of mud crab from upper side. The direction tends to inside (A) Inner Frontal side, (B) Outer Frontal side and Outer Back side dan (C) Inner Back side (Insausti et al., 2012). Figure 9 shows that mud crab has the lowest visual acuity direction at the inner-back side. Observation of the density of eye cells in different life stage showed that the direction tend to be similar as shown in Fig. 9.

\section{Discussion}

The diameter of eye cells is increase followed by the increase of carapace width. With its increases, the number of eye cell is appeared lower than the last stadia at the same visual field. Eye cells diameters grew as the increase of the body size and age. A reduction of cone cell density due to the development of eye cells was changed along with the growth of the body size and stadia of crabs. This was observed with a fix observation area under microscope (Fitri, 2005; 2012; Fitri et al., 2017).

Minimum Separable Angle (MSA) as the basis for calculating visual acuity mud crab is different between juvenile, adult and adult stadia with different number of cone cells (Fitri, 2012; Fitri et al., 2017). Adult stage have lower MSA value than sub adult and sub adult have lower MSA value than juvenile meaning that the growth of crab age will detract MSA value. In the Juvenile stage, the minimum separable angle is decreased gradually with the increase of visual acuity showing opposite values. Therefore, mud crabs will have a good visual acuity due to its gradual increase following the growth of the carapace width. Mud crabs Visual acuity describes inter reciprocal relation between VA and MSA. VA depends on eye cell density and eye diameter (Purbayanto, 1999). Shiobara et al. (1998), Visual acuity depends on 2 factors which are diameters of lens and the density of cone cell in retina. Epifanio and Cohen (2016), by improving the distance of focal lens will increase its visual acuity. Visual acuity in the juvenile stadia (carapace width $<7 \mathrm{~cm}$ ) between $0.60 \times 10^{-3}$ $7.4 \times 10^{-3}$ is increased gradually in sub adult stages (carapace width $7-11 \mathrm{~cm}$ ) between $9.1 \times 10^{-3}-15.4 \times 10^{-3}$ and adult stage between $16 \times 10^{-3}-19.6 \times 10^{-3}$. The visual acuity index indicates that the visual acuity in adult crab is better than sub adult and juvenile. In addition, visual acuity in the eyes of mud crab between right and left eye is not significantly different. Based on previous research by Epifanio and Cohen (2016), visual acuity and minimum intensity evident showed that the results are similar for both monocular and binocular vision.

Visual acuity will help crab to see in the field as supporting its life like prey, socialization with their neighbor, spawning and migration. Zeil and Hemmi (2006), state that each eyes crab has panoramic visual by scanning eye movement. Vision in wide variety behavioral including predator avoidance. The visual acuity analyze in the different life stage to know their capability detect the object by its eyes. Previous research by Clarck (1935), visual acuity of fiddler crab that there are some radius of clear zone is measure of the maximum distance that crabs can see an object. Purbayanto (1999) and He (1989), diameters of lens will raise along with body length, while the number of con cell decrease and opposite with the body length growth.

The visual acuity index data as a basic to analyze the ability of mud crab when first seen objects with a certain diameter, or known as Maximum Sighting Distance (MSD) (Insausti et al., 2012; Epifanio and Cohen, 2016; Fitri et al., 2017). The existence of a positive correlation between the diameter of objects viewed with the value of MSD in each stadia, means that the greater the diameter of the object will increase the ability mud crab to see objects on a certain stadia. MSD values are compared between stadia (juvenile, sub adult and adult), the more mud crab stadia will increase with the greater the diameter of the object being viewed, the adult stadia has the largest MSD value compared to the juvenile and sub adult stadia. In these researches can be assumed that the object size is bait, so MSD value will use to illustrate the maximum distance based on object size which is seen by the mud crab.

Visual axis is used to determine the visual direction. Information related to visual axis aims to know mud crab habits to see an object, because it will also affect mud 
habits in conducting activities of life (Tomsic, 2016). The observation by counting the total eye cell in 4 part the visual direction of crab tend to frontal that is: Innerfront following outer-frontal side, outer-back side and the last is inner- back side. The lowest number of eye cell is inner-bottom side, so the position behind its body called dead zone. Another research by Luo et al. (2003), shows that the morphology of eye mud crab were observed with Electron Microscopes (EM) there was a thumb-shape area (upper eye) with no ommatidia on the back compound eye. Gunarso (1985), fish visual axis has not be exceed by its range called dead zone. The visual direction of fish shows crab's daily life.

The sensitivity of eye direction in their natural life like burrowing a hole, prey and hide in the mud. Luo et al. (2003), the morphology in the different direction may relate to the deep endence of species on the visual sense of their natural habitats. Therefore, mud crab only live in flat environment compatible with their body shape, as reported by Nalbach and Gerbera (1987), species with flat environments only opto-kinetic response along and above the equator of the eye. Zeil et al. (1986), stated that the acute zone for horizontal resolving power in each type of crab are similar. The direction based on the density of eye cell show in the different life stage are similar on each other to the inner frontal and the inner back side is the lowest density of eye cell and usually called dead zone area. The dead zone area is an area where crab or fish can't see an object. The information of dead zone area is useful for fisherman to catch the fish easily.

Visual direction affected by the density of eye cell in each eye side whose have high sensitivity with illumination. According to Luo et al. (2003), the morphology in the difference direction may be related to the deep endence of species on the visual sense of their natural habitats. The highest eye cell is in frontal inner side, it mean that the visual direction tend to front side beside their capabilities on walk in sideway. The second of visual direction is in outer front and outer back side, crabs will use their capabilities to see an object in the right or left side of their body when moving. Phelan and Grubert (2007), Mud crab set their eyes on stalks. Clarck (1935), the movement in visual field follow the object and tend to move at opposite direction, if the object is moved from the animal's left to its right the crab will moved to the left.

The relationship between visual axis and mud crab habits in adaptation to the surrounding environment is their tendency to move their body with walking in the sideway to the left or right of their body. Sometimes they will follow their eye direction to the right and left because crabs can see to the right or left by calculating the density of eyes. Barnes and Jon (1990), the eye movement in the crab Cardisoma sp. show that eye compensate for locomotor turns by moving in the opposite direction to the body. Therefore, mud crab is easier to catch from the back side than frontal side.
When mud crab moves from the right to the left side because its avoidance from the object on right side, it will easy to catch them from the left but if mud crab moved from the right side and tend to attract the object in the left side, it not easy to catch from the left because crab will focus on the object. Yuan et al. (2001), the back side of crab is a closed cells without ommatidia. Ommatidia place in cornea with 2 corneagoneus cells 4 and 7 retinal cell. Crystalcone placed on the distal part of retina. Under crystaline cone consist of 7 retinular cells as a major part of retina.

Visual acuity of crabs will improve with their growth and age. The adult crabs can see an object better than sub adult or juvenile, but if the mud crabs molting their visual acuity will diminish. Fergus (2012), visual signals play a role in the sexual, most species' visual displays include variations. Visual signals have been most studied in fiddler crabs genus Uca. Mud crabs with inner frontal direction as longitudinal direction is corresponds with their environmental habit, they live in the flat world. Land and John (1995), the horizontal resolution is nearly constant trough out the eye and as reported by Epifanio and Cohen (2016), the visual acuity and minimum intensity are similar both monocular and binocular vision.

\section{Conclusion}

The visual acuity of the mud crabs can be measured by calculating the total number of eye cell by means of its dissection. The visual acuity in different life stage was different within its visual power was developed from juvenile- sub adult-adult stage. In mud crabs, the visual acuity from juvenile to adult is $6 \times 10^{-3}$ to $19.6 \times 10^{-3}$. Maximum sighting distance of mud crabs is increased linear by their final life stage and its diameter. Maximum sighting distance in juvenile towards 20 to 50 $\mathrm{mm}$ of object is 0.4 to $1.03 \mathrm{~m}$, sub adult 0.63 to $1.5 \mathrm{~m}$ and adult is 1.1 to $2.7 \mathrm{~m}$. Visual axis indicates that the visual direction of crabs and among 3 life stage tend to inner frontal direction, its depends on the total number of eye cell and the visual axis and direction are similar among different life stage to inner frontal side.

\section{Acknowledgement}

The authors wish to acknowledge Fish Health Laboratory, Bogor Agriculture University for the facility support, Mr. Mudofar as Fisherman for catching mud crabs, Mauidzatul Hasanah, Aziz Rifianda, Adi Nuryanto for the support and accompanied us in the field.

\section{Author's Contributions}

Aristi Dian Purnama Fitri: Designed the research and experiment; prepared the manuscript.

Herry Boesono: Prepared the samples and searched the literature. 
Agus Sabdono: Analyzed the data and helped to prepare the manuscript.

Fahresa Nugraheni: Conducted the experiment.

\section{Conflict of Interest}

The author declare that there is no conflict of interest regarding the publication.

\section{References}

Barnes, W. and P. Jon, 1990. The visual acuity of the fiddler-crab, uca pugnax. J. General Psycol., 19: 311-319.

Clarck, L.B., 1935. Sensory basic and fundamental role of eye movement elicited during locomotion in the land carb cardisoma Guanhumi. J. Experimental Biology, 154: 99-119.

Epifanio, C.E. and J.H. Cohen, 2016. Behavioral adaptations in larvae of brachyuran crabs: A review. J. Exp. Marine Biol. Ecol., 482: 85-105. DOI: $10.1016 /$ j.jembe.2016.05.006

Fergus, J.B., 2012. The role of vision in sexsual signaling in the blue crab. Departement of Biology of Duke University, London.

Fitri, A.D.P., 2005. Relationship of Visual Acuity and Visibility of Maximum Visibility on Mud Fish Groupers (Ephinephelus tauvina). J. Marine Sci., 10: 11-16.

Fitri, A.D.P., 2012. Handbook Fish Behaviour. 1st Edn., UPT Diponegoro University Press, ISBN-13: 978-602097-318-0, pp: 125.

Fitri, A.D.P., H. Boesono, A. Sabdono, F.N. Supadminingsih and N. Adlina, 2017. The mud crab (Scylla serrata) behavior in different inclination angles of funnel and escape vent for trap net. AACL Bioflux, 10: 182-190.

Gunarso, W., 1985. Fish behaviour in relation to the capture device and fishing tactics. Department of Utilization Fisheries Resources, Faculty of Fisheries and Marine Science, Bogor Agriculture Institute, IPB Press.

Grubert and M. Phelan, 2007. Guide to catching mud crab in the Northern Territory. Coastal Research Unit of Fisheries Darwin, Fishnote.

Guma'a, S.A., 1982. Retinal development and retinomotor responses in perch, Perca fluviatilis L. J. Fish Biol., 20: 611-618. DOI: $10.1111 / \mathrm{j} .1095-8649.1982 . t b 03960 . \mathrm{x}$

He, P., 1989. Fish behaviour and its aplication in fisheries. New Foundland Canada, Labrador Institute of Fisheries and Marine Technology.

Insausti, T.C., J. Defrize, C.R. Lazzari and J. Casas, 2012. Visual fields and eye morphology support color vision in a color-changing crab-spider. Arthropod Struct. Dev., 41: 155-163.

DOI: $10.1016 /$ j.asd.2011.11.003
Land, M. and L. John, 1995. The visual control of behaviour in fiddler crabs: II trcaking control system in courtship and defence. J. Comparative Physiol., 177: 91-103. DOI: 10.1007/BF00243401

Luo, W.J., C. Hang, Z. Hui and Q.S. Chun, 2003. Morphology and Ultrastructure of the compound eye in the mud crab (Scylla serrata). Zool. Res., 24: 220-226. http://europepmc.org/abstract/cba/523400

Nalbach, H.O. and G. Nalbach, 1987. Distribution of optokinetic sensitivity over the eye of crabs: Its relation to habitat and possible role in flow-field analysis. J. Comparative Physiol. A, 160: 127-134. DOI: $10.1007 / \mathrm{BF} 00613448$

Phelan, M. and Grubert, 2007. The life cycle of the mud crabs. Coastal Research Unit, Fisheries, Darwin Department of Primary Industry Fisheries and Mines.

Purbayanto, A., M. Riyanto and A.D.P Fitri, 2010. Physiology and fish behavior in fishing equipment. Bogor Agriculture University Press.

Purbayanto, A., 1999. Behavioral studies for improving survival of fish in mesh selectivity of sweeping trammel net. Graduate School of Fisheries, Tokyo University of Fisheries Tokyo.

Shiobara, Y., S. Akiyama and T. Arimoto, 1998. Developmental changes in the visual acuity of red sea bream Pagrus major. Fisheries Sci., 64: 944-947. DOI: 10.2331 /fishsci.64.944

Tamura, T., 1957. A study of visual perception in fish, especially on resolving power and accommodation. Bull. Japanese Society Scientific Fisheries, 22: 536-557. DOI: $10.2331 /$ suisan.22.536

Tomsic, D., 2016. Visual motion processing subserving behavior in crabs. Curr. Opin. Neurobiol., 41: 113-121. DOI: $10.1016 /$ j.conb.2016.09.003

Yuan, W.J., C. Hang, Z. Hui and Q.S. Chun, 2001. Morphology and ultrastructure of compound eyein miers (Portunus trituberelilatus). Chinese J. Zool. Res.

Zeil, J., G. Nalbach and H.O. Nalbach, 1986. Eyes, eye stalks and the visual world of semi-terrestrial crabs. J. Comparative Physiol., 159: 801-811. DOI: $10.1007 / \mathrm{BF} 00603733$

Zeil, J. and J.M. Hemmi, 2006. The Visual Ecology of Fiddler Crabs. J. Comparative Physiol., 192: 1-25. DOI: $10.1007 / \mathrm{s} 00359-005-0048-7$ 